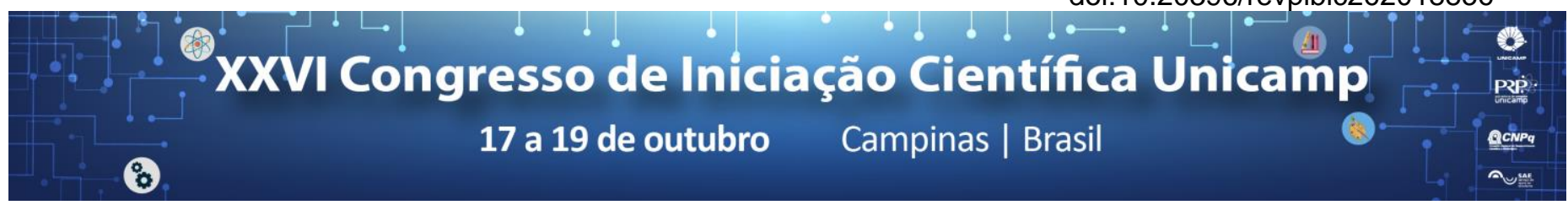

\title{
Facies analysis and paleosol characterization of Urucuia Group in the Sao Domingos - GO region
}

\section{Letícia Corrêa*, Alessandro Batezelli.}

\begin{abstract}
The Sanfranciscana basin is a wide intracratonic basin sub-divided in Abaeté sub-basin and Urucuia sub-basin which includes four Groups of Neo Paleozoic to Neo Cretaceous ages, among them there is the target of this study, the Urucuia Group (Upper Cretaceous). The Urucuia Group has the largest rock volume and areal distribution of the basin. Its rocks constitute two Formations, the basal named Posse overlaid by Serra das Araras Formation. In a continental environment where there is a few fossil contents, the paleosol study can bring important information about climatic and geomorphologic conditions, and biological activity being possible to do an environmental reconstruction. Therefore, this project aims to elaborate a paleoenvironmental model to the Upper Cretaceous of the Sanfraciscana basin through facies analysis and paleosol characterization. The fieldwork was accomplished in the outcrops of the Urucuia Group situated near to São Domingo (GO) town. Outcrop descriptions, photographic registration, and sample collection to laboratory analysis were the methodology applied. The outcrop description was made by the identification of lithologies, textures, sedimentary structures, paleocurrents, fossil content, bed geometry, as well as paleosol macromorphologic description.
\end{abstract}

Key words: Upper Cretaceous, lithofacies, fluvial-aeolian environment.

\section{Introduction}

The Sanfranciscana basin is an intracratonic basin elongated in the $\mathrm{N}-\mathrm{S}$ direction situated in the centralnorth area of Brazil. It represents the Phanerozoic cover from Sao Francisco Craton, and it can be sub-divided in Abaeté sub-basin na Urucuia sub-basin ${ }^{1},{ }^{2}$ which includes four Groups (Neo Paleozoic to Neo Cretaceous) 1. Among these there is this study target, the Urucuia Group (Upper Cretaceous). The Urucuia Group has the largest rock volume and areal distribution of the basin. Its rocks constitute two Formations, the basal named Posse overlaid by Serra das Araras Formation 1, 2. There are scarce studies about this Group, for this reason the present study accomplished a detailed facies analysis and a paleosol macro characterization of the Formations of the Urucuia Group in its outcrops located in the Goias state aiming to detailed depositional and pedogenetic aspects which can contribute to the understanding of the depositional environment during the Late Cretaceous.

\section{Results and Discussion}

Four lithofacies composed of fine to medium tabular sandstones with trough cross stratification; gravelly sandstones with fine to coarse granulometry, granules and pebbles imprint the forsets and the coset bases, concave geometry filled by smooth concave and tabular bars, trough cross stratification sometimes occurring as festons, wave and plane parallel laminations are less common; these sandstones are in part massive; red massive mudstones with desiccation cracks feature; and two paleosol profiles with sandy and massive aspect was obtained as a result of this study. These were assigned in three facies association: eolian, fluvial-aeolian, and paleosol which have bounding surfaces varying from first to fifth order ${ }^{3}$. Paleocurrent data revealed two different and opposite flux directions of sedimentation. These mentioned characteristics enable to interpret and conclude that the studied outcrop rocks were generated in an eolian environment as dune field, with a transition to a fluvial-aeolian environment with a wide sand sheet with dunes reworked by ephemeral braided rivers and flood plains. The paleossol represents a reduction in sedimentary input or a deposition break, also suggesting a rise in the hydric availability.

\section{Conclusions}

This project achieved its goals. It was possible to establish a paleoenvironmental reconstruction of the rocks from Posses and Serra das Araras Formation units of Urucuia Group, with focus on facies analysis and paleosols, due to fieldwork, previous knowledge, the study of the literature, and the supervisor assistance.

The scientific initiation (SI) was important to the student formation contributing to fixation and improvement of the knowledge in sedimentology and stratigraphy areas.

\section{Acknowledgement}

The author thank the Conselho Nacional de Desenvolvimento Científico e Tecnológico - CNPq/PIBIC for the SI scholarship, and the FAPESP 2015/17632-5 project for their sponsorship of this research. Likewise, gratitude to the supervisor Prof. Dr. Alessandro Batezelli, to the Prof. Dr. Francisco Ladeira, and to the M. Diego Nascimento.

\footnotetext{
1 Campos J.E.G. \& Dardenne M.A. Estratigrafia e sedimentação da Bacia Sanfranciscana: uma revisão. Revista Brasileira de Geociências, v. 27, n.3, 257282, 1997a.

2 Campos J.E.G. \& Dardenne M.A. Origem e evolução tectônica da Bacia Sanfranciscana. Revista Brasileira. Geociências, v. 27, n.3, 283-294, 1997b.

3 Miall A.D. The Geology of Fluvial Deposits: Sedimentary Facies, Basin Analysis and Petroleum Geology. Berlin, Springer, 582 p., 1996.
} 